\title{
Frequency and function of $\mathrm{KIR}^{+} \mathrm{CD} 8^{+} \mathrm{T}$ cells in HTLV-1 infection
}

\author{
Katie Twigger ${ }^{1 *}$, Aileen Rowan ${ }^{1}$, Nafisa-Katrin Seich al Basatena', Aidan MacNamara', Christelle Retiere ${ }^{3}$, \\ Keith Gould ', Graham P Taylor², Becca Asquith', Charles RM Bangham \\ From 16th International Conference on Human Retroviruses: HTLV and Related Viruses \\ Montreal, Canada. 26-30 June 2013
}

An efficient antiviral cytotoxic T lymphocyte (CTL) response to HTLV-1 infection maintains a low proviral load (PVL), reducing the risk of HAM/TSP. Host genotype, particularly of HLA class I, is a major determinant of CTL efficiency, and the influence of specific HLA class I alleles on HTLV-1 immunity is well documented. We recently showed that killer immunoglobulin-like receptor (KIR) genotype also influences CTL efficiency, by affecting HLA class I-mediated HTLV-1 immunity. Possession of the KIR2DL2 gene enhanced the effect of known protective or detrimental HLA class I alleles on PVL and HAM/TSP risk. This study aims to profile the frequency and function of $\mathrm{CD} 8^{+} \mathrm{T}$ cells expressing KIR2DL2 and other KIRs in HTLV-1 infection. Analysing total KIR expression showed the presence of $\mathrm{KIR}^{+} \mathrm{CD} 8^{+} \mathrm{T}$ cells, $\mathrm{NK}$ cells and $\mathrm{CD} 4^{+} \mathrm{T}$ cells in PBMCs from uninfected and HTLV $-1^{+}$donors. A subset of HTLV-1 ${ }^{+}$donors had high frequencies of total $\mathrm{KIR}^{+} \mathrm{CD} 8^{+} \mathrm{T}$ cells. Analysing individual KIRs revealed the presence of KIR2DL2 ${ }^{+} \mathrm{CD} 8^{+}$ $\mathrm{T}$ cells in HTLV $-1^{+}$donors. Preliminary data from PBMCs stimulated with Tax peptides indicates that KIR2DL2 ${ }^{+} \mathrm{CD}^{+} \mathrm{T}$ cells constitute a very small proportion of the IFN $\gamma$-producing Tax-specific $\mathrm{CD}^{+} \mathrm{T}$ cell population. HTLV-1 ${ }^{+}$asymptomatic carriers had higher frequencies of IFN $\gamma$-producing Tax-specific KIR2DL2 ${ }^{+} \mathrm{CD}^{+}{ }^{+} \mathrm{T}$ cells than donors with HAM/TSP did. Further work is underway to characterise the function of Tax-specific CD8 ${ }^{+} \mathrm{T}$ cells by staining with anti-CD107a, anti-IFN $\gamma$ and the HLA-A2/Tax ${ }_{11-19}$ pentamer, and to compare the frequency and function of KIR2DL2 $2^{+} \mathrm{CD} 8^{+}$ $\mathrm{T}$ cells with those expressing other 2-domain KIRs.

\section{Authors' details}

${ }^{1}$ Section of Immunology, Imperial College London, UK. ${ }^{2}$ Department of Genito-Urinary Medicine and Communicable Diseases, Imperial College London, UK. ${ }^{3}$ Immunovirologie et polymorphisme génétique, Etablissement Français du Sang, Université de Nantes, Nantes, France.

Published: 7 January 2014

doi:10.1186/1742-4690-11-S1-P79

Cite this article as: Twigger et al:: Frequency and function of $\mathrm{KIR}^{+} \mathrm{CD} 8^{+}$ Tcells in HTLV-1 infection. Retrovirology 2014 11(Suppl 1):P79.

* Correspondence: katie.twigger09@imperial.ac.uk

${ }^{1}$ Section of Immunology, Imperial College London, UK

Full list of author information is available at the end of the article

Submit your next manuscript to BioMed Central and take full advantage of:

- Convenient online submission

- Thorough peer review

- No space constraints or color figure charges

- Immediate publication on acceptance

- Inclusion in PubMed, CAS, Scopus and Google Scholar

- Research which is freely available for redistribution
() Biomed Central 